\title{
Socioeconomic, environmental and social impacts of a concentrated solar power energy project in Northern Chile
}

\author{
Irene Rodríguez-Serrano ${ }^{1, *}$, Natalia Caldés ${ }^{1}$, Cristina De la Rúa ${ }^{1}$, Yolanda Lechón ${ }^{1}$, and Alberto Garrido ${ }^{2}$ \\ ${ }^{1}$ Energy Systems Analysis Unit, Environmental, Energetic and Technological Research Center, CIEMAT, \\ Avenida Complutense 40, 28040 Madrid, Spain \\ ${ }^{2}$ Management of Agricultura and Environmental Risks Research Center, CEIGRAM, Avenida Complutense s/n, 28040 Madrid, \\ Spain
}

\begin{abstract}
Concentrated solar power deployment could potentially play an important role in the sustainable development strategy of Chile, the country with the highest solar potential in the world. Using an Input-Output methodology, this work conducts a sustainability assessment of the installation, operation and maintenance of an 110 MW concentrated solar power tower plant in Chile in terms of economic activity, job creation, energy consumption and $\mathrm{CO}_{2}$ emissions. Additionally, using the Social Hotspot Database, a preliminary social risk analysis in those economic sectors with the highest employment creation is conducted. Assuming domestic provision of all goods and services, results show that the associated total socioeconomic impacts during the whole lifetime of the plant would amount to 3,124 million US\$, a multiplier effect of 2.2 and a ratio of indirect per direct job creation of 1.21. Additionally, results also show that direct and indirect economic activities required by the project would generate $64.36 \mathrm{~g} \mathrm{CO}_{2}$ per $\mathrm{kWh}$. Finally, the social assessment indicates the existence of a high unemployment risk in those sectors that would result most stimulated.
\end{abstract}

\section{Introduction}

The energy sector is one of the largest consumers of natural resources and responsible for Green House Gas (GHG) emissions. One way to reduce GHG emissions worldwide is to progressively substitute fossil fuel technologies by renewable ones. The country with the highest solar energy potential is Chile, in particular the Atacama Desert in the North of the country. The need to promote a wide portfolio of renewable energy technologies in Chile is critical due to the seasonality of its large hydropower energy and also its energy dependency from fossil fuels, mostly imported [1].

In Chile, due to its outstanding solar resource, concentrated solar power (CSP) is one of the most promising renewable energy technologies. Compared to other technologies, the main advantage of CSP is its storage capacity [2]. The most suitable region in terms of solar irradiation within the Atacama Desert is Antofagasta, which has large energy demand mainly from the mining sector [1].

Thus, given the large energy consumption of the mining sector, the huge solar potential and the expected cost reduction of the technology, CSP could likely play a key role in the Chilean energy mix and contribute to the decarbonization efforts of the country. In this sense, this work conducts a sustainability assessment of the flagship

\footnotetext{
* e-mail: irene.rodriguez@ciemat.es
}

CSP project in Antofagasta "Cerro Dominador" applying the Input-Output (I-O) framework as well as the Social Hotspot Database (SHDB).

\section{Methodology}

I-O methodology analyses the response of economic sectors due to an increase in the demand of goods and services caused by a project. This methodology was first developed in 1936 by Leontief [3]. I-O analysis is based on the I-O Tables (IOT), which displays the intersectorial relations among the economic sectors of a country. From the IOT, it is possible to obtain the technical coefficients, which indicate the consumption that one sector requires from another sector to produce one single unit monetary unit [4].

Additionally, the IOT display the added value of each economic sector and the final consumption of private and public sectors. Equation (1) shows the final production calculation, which accounts for both direct and indirect effects in the economy (indirect effects are the ones produced by the effect that the new investment has on new flows of purchases and sales among economic sectors) [5].

$$
X=(I-A)^{-1} \cdot Y
$$

where: $X$ is the final production; $A$ is the technical coefficient matrix; $Y$ is the final consumption demand; and $(I-A)^{-1}$ is the Leontief inverse matrix, which quantifies the direct and indirect requirements to satisfy a certain final demand. 
Due to the interdependency among economic sectors, the development of any project involves a stimulation of various economic sectors. Such effect is the so-called multiplier effect and indicates how much the total income of a country increases for every monetary unit invested in a project. The multiplier effect is the ratio between total effects (direct and indirect effects) and direct effects [6].

Moreover, the methodology allows estimating the induced effects, which account for the economic effects generated by the expenditures of the workers involved in the project.

An extension of this methodology consists on assessing other type of effects - such as job creation and $\mathrm{CO}_{2}$ emissions - per unit of output for each economic sector, as shown in equation (2) [7]

$$
\Delta X \cdot Z_{i}=Z_{i}(I-A)^{-1} \cdot \Delta Y
$$

where: $\Delta X$ is the total (direct and indirect) increase in goods and services; $(I-A)^{-1}$ is the Leontief inverse matrix; $\Delta Y$ is the final demand and $Z_{i}$ is the environmental or socioeconomic vector, which indicates the employment, emissions, energy consumption, etc. per unit of production for each economic sector included in the IOT.

One of the advantages of the methodology is that the IOT are usually available from the Statistics databases. However, it also faces some limitations: all informal transactions in the economy are not accounted for and IOT are only published and updated every few years [7].

With respect to social impacts, the SHDB is used to identify the main social risks in those sectors more affected by the project in terms of employment. The SHDB classifies different social themes in four risk values "very high", "high", "medium" and "low" in order to obtain the so called "Social Hotspot Index" (SHI), which compares, in a quantitative way, the different social risks classified in five impact categories among sectors and countries (eq. (3)). A SHI close to a hundred value means that there exist very high social risks within an impact category [8].

$$
S H I_{c a t}=\frac{\sum_{T=1}^{n}\left(R_{a v g} \cdot W_{T}\right)}{\sum_{T=1}^{n}\left(R_{\max } \cdot W_{T}\right)},
$$

where: $S H I_{\text {cat }}$ is the total index of the social risks of each impact category; $T$ is the social theme; $n$ is the number of themes within an impact category; $R_{a v g}$ the average risk of each social theme and $R_{\max }$ is the maximum risk of each theme and $W_{T}$ is the assigned weight to each social theme.

The principal advantage of the SHDB is that not only common socioeconomic impacts (e.g. employment) are considered but also other unusually social impacts (e.g. human rights, etc.) [8].

\section{Data and assumptions}

The principal assumptions considered in this work are: - domestic manufacturing of all components;
- 1 year of plant construction;

- 30 years plant lifetime;

- non-use of additional energy;

- the electricity consumption of the plant comes from the Chilean electricity system.

The principal characteristics of CSP Cerro Dominador plant are based on [9] and [10]: the location of the plant will be in Antofagasta (Chile) and its operation expected start date would be on June 2018. With a $94.5 \%$ on-peak capacity factor, it would produce $27,318 \mathrm{GWh}$ in its lifetime.

The direct and indirect economic effects have been calculated based on the Chilean IOT and investment and O\&M cost data from other plants. The Chilean IOT has been obtained from the Organization for Economic Cooperation and Development (OECD) database [11]. The reference year is 2003 and contains 37 economic sectors.

The investment costs have been estimated based on cost data of a 17-MW Spanish plant [6] and have been extrapolated to a 100-MW plant with 15 storage hours [12]. The case study investment cost breakdown is described below: $37 \%$ solar field, 14\% tower, $6 \%$ storage system, $12 \%$ power block, $1 \%$ land, $8 \%$ engineering and insurances, $6 \%$ construction, $6 \%$ financial costs, $5 \%$ balance of plant and $5 \%$ other expenses. The total investment cost assumed is 1,338 US\$M, which is similar to the one in the Environmental Impact Statement $(1,300 \mathrm{US} \$ \mathrm{M})$ [10]. A cost reduction of $12 \%$ has been assumed by 2015 according to the International Renewable Energy Agency (IRENA) [13].

Based on the annual O\&M cost of a 100-MW plant with 9 hours of storage of $6,500,000 \$ /$ year [14], it has been assumed that the O\&M cost (without personnel costs) for this case study would amount to $4,877,704 \$$ /year. The discount rate considered is $5 \%$ [6]. The O\&M breakdown considered is [12]: $31 \%$ solar field and storage system; $20 \%$ financial costs; $25 \%$ personnel costs; $14 \%$ power block and $10 \%$ variable costs.

For the assessment of the induced effects, it has been considered a personnel cost data in the O\&M phase of $1,622,296 \$$ year based on [12] and [14]. Also the propensity to consume considered for Chile is 0.67 [15]. The Chilean household expenditures distribution across economic sectors in 2003 is extracted from [16].

Regarding employment, the Chilean National Statistics Institute contains data for nine economic sectors in the year 2003 (INE) [17]. In order to overcome the data gap between the 9 economic sectors from Chilean INE and the 37 sectors of the IOT, the employment vector of the Latin American country of Brazil available in the World IO Database (WIOD) has been considered [18].

With regards to energy consumption, most data come from the Chilean National Emissions Inventory (NEI) [19]. For the disaggregation of the 37 the economic sectors of the IOT, the National Energy Balance (BNE) from the National Energy Commission (CNE) in 2003 has been consulted [20]. Finally, due to the large contribution of fossil fuels in the Chilean energy mix, the distribution of the $\mathrm{CO}_{2}$ emission vector among IOT economic sectors is based on the energy consumption vector. 
Table 1. Direct, indirect, induced economic effects and employment generation caused by the plant.

\begin{tabular}{|c|c|c|c|c|c|c|c|c|c|}
\hline & \multicolumn{2}{|l|}{$\begin{array}{l}\text { Direct } \\
\text { US\$M }\end{array}$} & \multicolumn{2}{|l|}{$\begin{array}{l}\text { Indirect } \\
\text { US } \$ M\end{array}$} & \multirow{2}{*}{$\begin{array}{l}\text { Induced } \\
\frac{\mathrm{US} \$ \mathrm{M}}{\mathrm{O} \& \mathrm{M}}\end{array}$} & \multicolumn{2}{|c|}{$\begin{array}{l}\text { Direct } \\
\text { employments (1000) }\end{array}$} & \multicolumn{2}{|c|}{$\begin{array}{l}\text { Indirect } \\
\text { employments (1000) }\end{array}$} \\
\hline & Investment & $\mathrm{O} \& \mathrm{M}$ & Investment & $\mathrm{O} \& \mathrm{M}$ & & Investment & $\mathrm{O} \& \mathrm{M}$ & Investment & O\&M \\
\hline 1. Agri & 0 & 0 & 39 & 4 & 2 & 0 & 0 & 3 & 0 \\
\hline 2. Min. & 0 & 0 & 50 & 5 & 1 & 0 & 0 & 0 & 0 \\
\hline 3. Food & 0 & 0 & 49 & 5 & 4 & 0 & 0 & 1 & 0 \\
\hline 4. Textile & 0 & 0 & 48 & 5 & 2 & 0 & 0 & 5 & 0 \\
\hline 5. Wood & 0 & 0 & 41 & 5 & 2 & 0 & 0 & 1 & 0 \\
\hline 6. Paper & 0 & 0 & 42 & 5 & 1 & 0 & 0 & 0 & 0 \\
\hline 7. Petrol & 0 & 0 & 44 & 5 & 2 & 0 & 0 & 0 & 0 \\
\hline 8. Chemic. & 88 & 3 & 68 & 6 & 1 & 1 & 0 & 1 & 0 \\
\hline 9. Plastic & 20 & 1 & 78 & 6 & 1 & 0 & 0 & 1 & 0 \\
\hline 10. NM min. & 371 & 4 & 109 & 5 & 1 & 9 & 0 & 3 & 0 \\
\hline 11. Bas. Metal & 58 & 0 & 66 & 5 & 1 & 1 & 0 & 1 & 0 \\
\hline 12. Fabr. Metal & 261 & 0 & 74 & 4 & 1 & 5 & 0 & 1 & 0 \\
\hline 13. Mach. & 122 & 1 & 83 & 5 & 1 & 3 & 0 & 2 & 0 \\
\hline 14. Offic. & 0 & 2 & 0 & 0 & 0 & 0 & 0 & 0 & 0 \\
\hline 15. Elec. Mach. & 147 & 1 & 78 & 4 & 0 & 33 & 0 & 17 & 1 \\
\hline 16. Comun. Eq. & 0 & 0 & 0 & 0 & 0 & 0 & 0 & 0 & 0 \\
\hline 17. Prec. Instr. & 0 & 0 & 0 & 0 & 0 & 0 & 0 & 0 & 0 \\
\hline 18. Mot. Veh. & 0 & 0 & 60 & 4 & 0 & 0 & 0 & 4 & 0 \\
\hline 19. Other transp. & 0 & 0 & 0 & 0 & 0 & 0 & 0 & 0 & 0 \\
\hline 20. Manuf. & 0 & 0 & 58 & 5 & 1 & 0 & 0 & 7 & 1 \\
\hline 21. Electr. & 1 & 7 & 33 & 8 & 2 & 0 & 0 & 0 & 0 \\
\hline 22. Const. & 89 & 0 & 100 & 5 & 1 & 3 & 0 & 3 & 0 \\
\hline 23. Whol. trade & 0 & 0 & 50 & 5 & 1 & 0 & 0 & 3 & 0 \\
\hline 24. Hotel \& Rest & 0 & 0 & 41 & 5 & 2 & 0 & 0 & 2 & 0 \\
\hline 25. Transp. \& Stor. & 0 & 0 & 33 & 4 & 3 & 0 & 0 & 1 & 0 \\
\hline 26. Telecom. & 0 & 10 & 40 & 9 & 1 & 0 & 0 & 1 & 0 \\
\hline 27. Fin. \& Ins. & 72 & 17 & 37 & 7 & 1 & 1 & 0 & 0 & 0 \\
\hline 28. R.E. act. & 2 & 0 & 33 & 4 & 0 & 0 & 0 & 0 & 0 \\
\hline 29. Rent. Mach. & 1 & 3 & 0 & 0 & 0 & 0 & 0 & 0 & 0 \\
\hline 30. Comp. Act. & 1 & 3 & 0 & 0 & 0 & 0 & 0 & 0 & 0 \\
\hline 31. R\&D & 1 & 1 & 0 & 0 & 0 & 0 & 0 & 0 & 0 \\
\hline 32. Oth. Bus. Act. & 103 & 15 & 39 & 5 & 0 & 3 & 0 & 1 & 0 \\
\hline 33. Public Admin. & 0 & 0 & 34 & 4 & 1 & 0 & 0 & 2 & 0 \\
\hline 34. Education & 0 & 0 & 18 & 2 & 1 & 0 & 0 & 1 & 0 \\
\hline 35. Health \& Soc. & 1 & 1 & 32 & 3 & 2 & 0 & 0 & 1 & 0 \\
\hline 36. Oth. Com. Serv. & 0 & 0 & 28 & 3 & 1 & 0 & 0 & 5 & 1 \\
\hline 37. Priv. Hous. & 0 & 0 & 36 & 2 & 0 & 0 & 0 & 0 & 0 \\
\hline Total & 1338 & 69 & 1541 & 143 & 33 & 60 & 1 & 68 & 6 \\
\hline
\end{tabular}

\section{Results and discussion}

4.1 Socioeconomic impacts: direct, indirect, induced economic effects and employment generation

Table 1 shows the total direct, indirect, induced economic effects and employment generation in the whole lifetime of the plant in both phases. The economic sectors names have been aggregated, the complete description of the economic sectors can be consulted in the UN-Stats Database [21].

The total effect that the solar plant would generate in the Chilean economy is 3,124 US\$M (millions US\$); being 1,407 $\$ \mathrm{M}$ direct effects; $1,683 \$ \mathrm{M}$ indirect effects and $33 \mathrm{US}$ $\$ \mathrm{M}$ induced effects. The multiplier effect would be 2.19 , which means that each dollar invested in the project would 
Table 2. Direct and indirect energy consumption and $\mathrm{CO}_{2}$ emissions in the whole plant lifetime.

\begin{tabular}{|c|c|c|c|c|c|c|c|c|}
\hline & \multicolumn{2}{|c|}{$\begin{array}{l}\text { Direct energy } \\
\text { consumption (10TJ) }\end{array}$} & \multicolumn{2}{|c|}{$\begin{array}{l}\text { Indirect energy } \\
\text { consumption }(10 \mathrm{TJ})\end{array}$} & \multicolumn{2}{|c|}{$\begin{array}{l}\text { Direct } \mathrm{CO}_{2} \\
\text { emissions (10Gg) }\end{array}$} & \multicolumn{2}{|c|}{$\begin{array}{l}\text { Indirect } \mathrm{CO}_{2} \\
\text { emissions }(10 \mathrm{Gg})\end{array}$} \\
\hline & Investment & $\mathrm{O} \& \mathrm{M}$ & Investment & O\&M & Investment & $\mathrm{O} \& \mathrm{M}$ & Investment & $\mathrm{O} \& \mathrm{M}$ \\
\hline 1. Agri & 0 & 0 & 3 & 0 & 0 & 0 & 0 & 0 \\
\hline 2. Min. & 0 & 0 & 3 & 0 & 0 & 0 & 0 & 0 \\
\hline 3. Food & 0 & 0 & 5 & 1 & 0 & 0 & 0 & 0 \\
\hline 4. Textile & 0 & 0 & 5 & 1 & 0 & 0 & 0 & 0 \\
\hline 5. Wood & 0 & 0 & 3 & 0 & 0 & 0 & 0 & 0 \\
\hline 6. Paper & 0 & 0 & 21 & 2 & 0 & 0 & 2 & 0 \\
\hline 7. Petrol & 0 & 0 & 25 & 3 & 0 & 0 & 2 & 0 \\
\hline 8. Chemic. & 10 & 0 & 8 & 1 & 1 & 0 & 1 & 0 \\
\hline 9. Plastic & 4 & 0 & 15 & 1 & 0 & 0 & 1 & 0 \\
\hline 10. NM min. & 207 & 2 & 61 & 3 & 70 & 1 & 21 & 1 \\
\hline 11. Bas. Metal & 204 & 0 & 231 & 18 & 21 & 0 & 24 & 2 \\
\hline 12. Fabr. Metal & 27 & 0 & 8 & 0 & 2 & 0 & 1 & 0 \\
\hline 13. Mach. & 11 & 0 & 7 & 0 & 1 & 0 & 1 & 0 \\
\hline 14. Offic. & 0 & 0 & 0 & 0 & 0 & 0 & 0 & 0 \\
\hline 15. Elec. Mach. & 17 & 0 & 9 & 0 & 1 & 0 & 1 & 0 \\
\hline 16. Comun. Eq. & 0 & 0 & 0 & 0 & 0 & 0 & 0 & 0 \\
\hline 17. Prec. Instr. & 0 & 0 & 0 & 0 & 0 & 0 & 0 & 0 \\
\hline 18. Mot. Veh. & 0 & 0 & 3 & 0 & 0 & 0 & 0 & 0 \\
\hline 19. Other transp. & 0 & 0 & 0 & 0 & 0 & 0 & 0 & 0 \\
\hline 20. Manuf. & 0 & 0 & 2 & 0 & 0 & 0 & 0 & 0 \\
\hline 21. Electr. & 5 & 24 & 114 & 26 & 0 & 2 & 8 & 2 \\
\hline 22. Const. & 9 & 0 & 10 & 0 & 1 & 0 & 1 & 0 \\
\hline 23. Whol. trade & 0 & 0 & 5 & 1 & 0 & 0 & 0 & 0 \\
\hline 24. Hotel \& Rest & 0 & 0 & 1 & 0 & 0 & 0 & 0 & 0 \\
\hline 25. Transp. \& Stor. & 0 & 0 & 59 & 7 & 0 & 0 & 4 & 1 \\
\hline 26. Telecom. & 0 & 0 & 1 & 0 & 0 & 0 & 0 & 0 \\
\hline 27. Fin. \& Ins. & 2 & 0 & 1 & 0 & 0 & 0 & 0 & 0 \\
\hline 28. R.E. Act. & 0 & 0 & 1 & 0 & 0 & 0 & 0 & 0 \\
\hline 29. Rent. Mach. & 0 & 0 & 0 & 0 & 0 & 0 & 0 & 0 \\
\hline 30. Comp. Act. & 0 & 0 & 0 & 0 & 0 & 0 & 0 & 0 \\
\hline 31. R\&D & 0 & 0 & 0 & 0 & 0 & 0 & 0 & 0 \\
\hline 32. Oth. Bus. Act. & 3 & 0 & 1 & 0 & 0 & 0 & 0 & 0 \\
\hline 33. Public Admin. & 0 & 0 & 0 & 0 & 0 & 0 & 0 & 0 \\
\hline 34. Education & 0 & 0 & 0 & 0 & 0 & 0 & 0 & 0 \\
\hline 35. Health \& Soc. & 0 & 0 & 0 & 0 & 0 & 0 & 0 & 0 \\
\hline 36. Oth. Com. Serv. & 0 & 0 & 0 & 0 & 0 & 0 & 0 & 0 \\
\hline 37. Priv. Hous. & 0 & 0 & 28 & 1 & 0 & 0 & 2 & 0 \\
\hline Total & 498 & 28 & 631 & 68 & 98 & 3 & 69 & 6 \\
\hline
\end{tabular}

generate $2.19 \$$ in the whole economy. Comparing these results with the economic effects of the $17 \mathrm{MW}$ Spanish plant, the total effect is $2,230 \mathrm{M} €$, with a multiplier effect of $2.3[16]$.

The principal economic sector that would be stimulated in the investment phase would be sector 10 "Other non-metallic minerals". This fact is due to the heliostats and the tower, which are the most expensive components of the plant. In the
O\&M phase, the largest directly stimulated sectors would be sector 27 "Financial intermediation" and sector 32 "Other business activities"; and sector 22 "Construction" indirectly.

The plant would create 134,949 new jobs in its whole lifetime, being 61,063 directs jobs and 73,887 indirect jobs. The ratio between indirect jobs over direct jobs would be 1.21. The sector with the largest job creation in the investment phase would be sector 15 "Electrical machinery 
and apparatus" due to the large contribution of this sector in the power block. In the O\&M phase, the most stimulated sectors would be sector 32 "Other business activities" related to the cleaning activities of the mirrors or the engineering jobs.

\subsection{Environmental impacts: direct and indirect energy consumption and $\mathrm{CO}_{2}$ emissions}

Table 2 shows the direct and indirect energy consumption and $\mathrm{CO}_{2}$ emissions in the whole plant lifetime in both investment and O\&M phases by economic sectors.

The energy consumption in the whole plant lifetime would be 12,243 TJ, being 5,225 TJ from direct consumption and 6,989 TJ from indirect consumption. In the investment phase, the largest energy consumption would come from sectors 10 "Non-metallic minerals" and 11 "Basic metals" due to the huge amount of energy they need for their production. In the O\&M phase, the most affected sector would be sector 21 "Electricity, gas and water supply".

Referring to $\mathrm{CO}_{2}$ emissions, the whole project would generate in the whole lifetime $1,759 \mathrm{Gg} \mathrm{CO}_{2}$, being 1,007 direct emissions and 753 indirect emissions. Sectors with highest emissions in the investment and O\&M phases are the same as in the energy consumption results based on high fossil fuel Chilean energy mix. Assuming that the plant would produce $27,318 \mathrm{GWh}$ in its whole lifetime, the amount of emissions per $\mathrm{kWh}$ would be $64.36 \mathrm{~g} \mathrm{CO}_{2} / \mathrm{kWh}$. This result is consistent with some estimation from literature: $60.1 \mathrm{~g}$ $\mathrm{CO}_{2} / \mathrm{kWh}$ from a parabolic trough plant [4].

\subsection{Social impacts}

The social risk analysis is performed in those sectors that show the largest total job creation as a result of the project (sector 22 "Construction", sector 15 "Machinery and electric equipments", sector 20 "Manufacturing", sector 12 "Fabricated metals" and sector 10 "Non-metallic mineral products"). The SHI for these sectors has a value of 60.81 , except in the construction sector which shows a higher value $\left(\mathrm{SHI}_{\text {const }}=67.5\right)$. This higher $\mathrm{SHI}$ value of the construction sector comes from the Labour Rights and Human Rights categories. Within the Labour Rights category, the breakdown in each social theme is: $5 \%$ forced labour, $19 \%$ freedom of association, $13 \%$ labour laws, $19 \%$ migrant workers, $5 \%$ poverty and $39 \%$ unemployment. In this way, the most important risk in the construction sector in Chile is unemployment ("very high risk" value). This is consistent with [22]. Additionally, the unemployment risk is also large in the other resulted sectors ("high" risk values).

\section{Conclusions}

This work has conducted the impact assessment of a CSP project in Chile in terms of economic stimulation, job creation, energy consumption, $\mathrm{CO}_{2}$ emissions and existence of social risks.

Under a 100\% local content assumption, the economic sectors most stimulated by the project would be "Non-metallic mineral", as well as others sectors like
"Construction" within others. The sector with the highest employment creation would be "Electrical machinery and apparatus".

With regards to environmental impacts, those sectors with the largest energy consumption and $\mathrm{CO}_{2}$ emissions would be "Non-metallic minerals" and "Basic metals".

Finally, the social risk assessment indicates that high unemployment is the most relevant social risk is those sectors most affected socioeconomically by the project. Therefore, the project would support the reduction of unemployment risks within these sectors.

To conclude, this paper has shown that CSP technology could play a relevant role as a driver to stimulate and diversify the Chilean economy, generate new employment opportunities and the associated environmental benefits as a renewable technology. Consequently, support policies that account for such positive externalities should be put in place to promote CSP in Chile.

\section{References}

1. T. Larraín, R. Escobar, Net energy analysis for concentrated solar power plants in northern Chile, Renew. Energy 41, 123 (2012)

2. A.L. Avila-Marin, J. Fernandez-Reche,F.M. Tellez, Evaluation of the potential of central receiver solar power plants: configuration, optimization and trends, Appl. Energy 112, $274(2013)$

3. W. Leontief, Quantitative Input and Output Relations in the Economic Systems of the United States, Rev. Econ. Stat. 18, 105 (1936)

4. C. De la Rua Lope, Desarrollo de la herramienta integrada "análisis de ciclo de vida - Input Outout análisis para España y aplicación a tecnologías energéticas avanzadas" (Madrid, España, CIEMAT, 2009)

5. D. Holland, S.C. Cooke, Sources of structural change in the Washington economy, Ann. Reg. Sci. 26, 155 (1992)

6. N. Caldés, M. Varela, M. Santamaría, R. Sáez, Economic impact of solar thermal electricity deployment in Spain, Energy Policy 37, 1628 (2009)

7. N. Caldés, Y. Lechón, Análisis de externalidades de las energías renovables, Tratado Energ. Renov. (Editorial Aranzadi) 951 (2010)

8. GreenDelta, Social Hotspot Database Introductory User Tutorial (York, Maine, USA, SHDB project, 2013)

9. CSP World, CSP World Map (CSP World Servicios Avanzados de Comunicación y Marketing SACM SL, 2014)

10. ABENGOA, Declaración de Impacto Ambiental de Cerro Dominador (Santiago, Chile, ABENGOA, 2013)

11. Organization for Economic Cooperation and Development Trade, Input-Output Tables

12. Fichtner, Assessment of technology options for development of concentrating solar power in South Africa (Johannesburg, South Africa, Fichtner, 2010)

13. B. Hoffschmidt, S. Alexopoulos, C. Rau, J. Sattler, A. Anthrakidis, C. Boura, B.O. Connor, P. Hilger, Conc. Solar Power 3 (2012)

14. G. Kolb, C. Ho, T. Mancini, J. Gary, Power tower technology roadmap and cost reduction plan (Albuquerque, New Mexico, Sandia National Laboratories, 2011) 
15. J. De Gregorio, Parte II. Comportamiento de los agentes económicos, Macroeconomía: teoría y política (Santiago, Chile, Pearson-Educación, 2007), pp. 61-160

16. Chile Central Bank, Clasificación del gasto en consumo final de los hogares e instituciones privadas sin fines de lucro por finalidad, periodo 2003-2007 (Santiago, Chile, Estudios Económicos Estadísticos del Banco Central de Chile, 2009)

17. Instituto Nacional de Estadísitica, Series Empalmadas Diciembre-Febrero 1986 a Diciembre-Febrero 2010 - Base Censo 2002 (Santiago, Chile, Instituto Nacional de Estadísticas [INE], 2014)
18. World Input-Output Database (WIOD) Data

19. Poch ambiental and Deuman, Inventario nacional de emisiones de gases de efecto invernadero (Santiago, Chile, Poch Ambiental, 2008)

20. Ministerio de Energía Balance Nacional de Energía

21. United Nations, United Nations Statistics DivisionClassifications Registry

22. Centro de Microdatos, Encuesta de Ocupación y Desocupación en el Gran Santiago: Infrome Trimestral de Empleo Marzo 2014 (2014)

Cite this article as: Irene Rodríguez-Serrano, Natalia Caldés, Cristina De la Rúa, Yolanda Lechón, Alberto Garrido, Socioeconomic, environmental and social impacts of a concentrated solar power energy project in Northern Chile, Renew. Energy Environ. Sustain. 1, 5 (2016) 